\title{
CONCEPTUAL MODEL FOR LITERACY IN A MULTICULTURAL ENVIRONMENT IN THE FIRST GRADE
}

\author{
Daniel Petrov Polihronov \\ Sofia University “St. Kliment Ohridski”, Faculty of Education, Sofia, Bulgaria \\ daniel.polihronoff@abv.bg
}

Original Scientific Paper doi:10.5937/jouproman5-14346

\begin{abstract}
In the article the author suggests a conceptual pedagogical model for literacy in a multicultural environment in the first grade. The empirical theoretical model is to be determined by: methodological aspects in Bulgarian Language and Literature education at the elementary stage; age characteristics and the development specifics of the child at an elementary school age and the sociocultural characteristics of the child's family environment and their impact on her personality. The model for achieving literacy for pupils in the first grade in a multicultural environment is a prerequisite for achieving literacy in ethnic minority pupils; mastering the standard Bulgarian language and successful social inclusion of ethnic minority children.
\end{abstract}

Key words: conceptual pedagogical model, literacy, multicultural environment

The command of language (spoken and written), including the process of primary literacy having to do with the knowledge of phonemes and letters and the development of reading and writing skills, is the foundation for the evolution of human consciousness - the most significant evolution on the planet. Through knowledge, through reading and writing, the need for spiritual development is discovered, because without language one cannot study and develop the potential within. Through language and speech, emotional literacy is achieved - emotional growth and managing emotions. Efficiency within society is realised for cognitive development, communication with others which is a human need necessary for the survival of each individual, equal opportunities, achievement of adequate balance with the environment in terms of communication.

The problem of functional illiteracy among ethnic groups is of present interest. The solution to the problem must be discovered at the elementary stage of primary education and deliberate measures must be taken to make students literate. This is a prerequisite not only for achieving a command of standard Bulgarian language but also for the successful social inclusion of ethnic minority children.

The facts are that when they start school, they "don't speak Bulgarian, the language of instruction, well enough or don't speak it at all" (Zdravkova, 2004) and that in the families of most of these pupils, the mother tongue is spoken exclusively and the pupils don't have the opportunity to practise speaking Bulgarian outside school. Together, these factors place the primary school teacher before a challenge, namely, to achieve effective literacy of the pupils.

The model of "treating everyone in the same way" used in the Bulgarian education system for decades is definitely wrong which is why we must redirect ourselves towards a variable model of teaching (Zdravkova, 2004). 
It is proposed, precisely for this reason, the construction of a specific model for achieving literacy of first grade pupils in a multicultural environment based on the conceptual ideas of already present models, which is to function as an innovative concept that is backed up by specifically working techniques to aid teachers so that a result-bearing and effective educational process can be realized for ethnic minority pupils, a process that guarantees pedagogical support aimed at the optimal preparation for school of each child.

Three main structures form the core of the model: theoretical - founded on the accomplishments of science, on ideas it accepts or creates in the construction of the concept of the phenomenon and of the search for solutions; conceptual - giving the mechanism of movement, of cooperation, of cohesion and connection of ideas in the direction of the solution; empirical-experimental - including both the meta-level (comparison and analysis) and the practical level - the concrete changes we envision in the situation or condition. (Rasheva-Merdzhanova, 2016)

At the theoretical level, theoretical formulations are to be analysed, which include issues about: the place of literacy in Bulgarian Language and Literature education at the elementary stage of primary education; the methodological requirements on literacy in Bulgarian Language and Literature education at the elementary stage of primary education and the specifics of literacy in a multicultural environment in the first grade. The methodological fundamentals of the model for literacy of first grade pupils must be drawn up.

The empirical level is to include the design of a model for literacy in a multicultural environment within the system of the elementary stage of primary education. The empirical theoretical model for literacy in a multicultural environment in the first grade is to be determined by: methodological aspects in Bulgarian Language and Literature education at the elementary stage; age characteristics and the development specifics of the child at an elementary school age and the sociocultural characteristics of the child's family environment and their impact on her personality (Application 1).

The construction and implementation of a model for literacy in a multicultural environment in the first grade, based on the aforementioned determinants, would lead to a higher level of children's competence formation in the areas of language, speech, communication, literature and sociocultural interactions. This competence would be, on one hand, commensurate with the standards of the Ministry of Education and Science on elementary school education, and on the other, with the conditions of work in a multicultural environment. In this respect the authors proposes the construction of a model along a horizontal axis (Application 2).

Testing this hypothesis and the cohesion of the movement mechanism of the proposed model's components can be checked through practical, empirical experimental assessment that includes the design and approbation of a system of teaching units (lessons) in Bulgarian Language and Literature as a main form of pedagogical interaction at the elementary stage of primary education, as well as a diademetric tool for determining the empirical and reflexive level of first graders' knowledge as per the key competences in the Bulgarian Language and Literature curriculum. 
At this stage of the structural modelling we shall organise a pedagogical experiment which includes three stages:

$$
\text { - } \quad \text { findings stage, }
$$
during which the language competence formation level is determined;

- transformation
(teaching, formation) stage -
implementation of the model for
literacy as a system of purposeful
fundamental and further forms of
pedagogical interaction aimed at
giving the children the opportunity
to comprehend and acquire the
knowledge, skills and relations
from the areas of competence as
per the Bulgarian Language and
Literature curriculum for the
elementary stage of primary
education;

- $\quad$ stage of assessment of the results from the experiment (concluding, control stage of the experiment) - comparing the results of assessing the children before and after the teaching stage of the experiment which have been gathered by means of the diagnostic tool.

To conduct the assessment at a practical level the following methods are to be used: pedagogical experiment approbation in the practice of an educational model for literacy as a system of units in Bulgarian Language and Literature in the first grade; questionnaires for teachers - determining the pedagogical competences of teachers regarding the specifics of achieving literacy in a multicultural environment; questionnaires for parents - determining parents' value positions (opinion and stance) regarding the necessity of making children literate; didactic testing determining the initial and post-program knowledge levels of first grade pupils in Bulgarian Language and Literature; retelling and composing text, the criteria for which, being empirically structured, are based on the formation of specific skills ${ }^{1}$.

The proposed will be implemented in three multicultural classes - one in a village, one in a town and one in a district city for the duration of one school year (30 school weeks) in the further schooling in Bulgarian language and literature classes under article 13, paragraph 13, section 2 of Regulation 6 of 2016 on mastering the standard Bulgarian language "for pupils taught at the elementary stage of primary education - up to 90 teaching hours [classes], with 3 teaching hours per week" (Regulation 6, 2016). (Application 3)

The model for achieving literacy for pupils in the first grade in a multicultural environment:

- $\quad$ is a prerequisite for achieving literacy in ethnic minority pupils; mastering the standard Bulgarian language and successful social inclusion of ethnic minority children;

$$
\text { - will provide }
$$
teachers working with such pupils with objective information about the reasons that underlie the bad command of Bulgarian and opportunities for individual classes for these pupils.

\footnotetext{
1 Criteria, empirically structured with students, based on the formation of specific skills for composing and retelling text, were compiled by Professor Neli Ivanova, PhD (Ivanova, 2014).
} 
In perspective, could be practically applicable in schools at the elementary stage of primary education. It could be multiplied in Bulgarian schools and even adapted and implemented in other countries, because literacy and mastering the official standard language, which is "not only a goal but also a means of education" (Zdravkova, 2004), will lead to successful social inclusion of ethnic minority children in contemporary society.

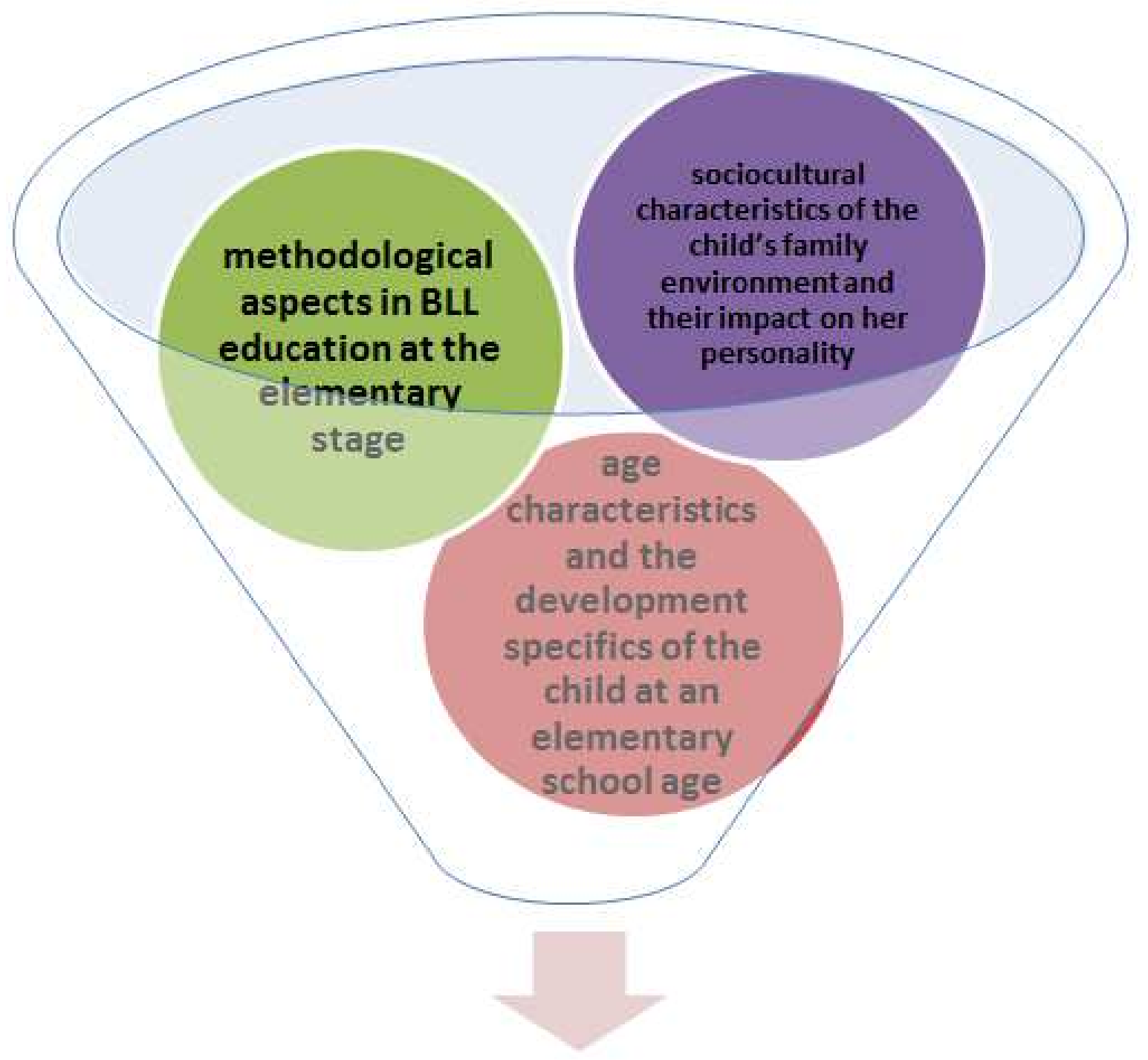

MODEL FOR LITERACY IN A MULTICULTURAL ENVIRONMENT IN THE FIRST GRADE 


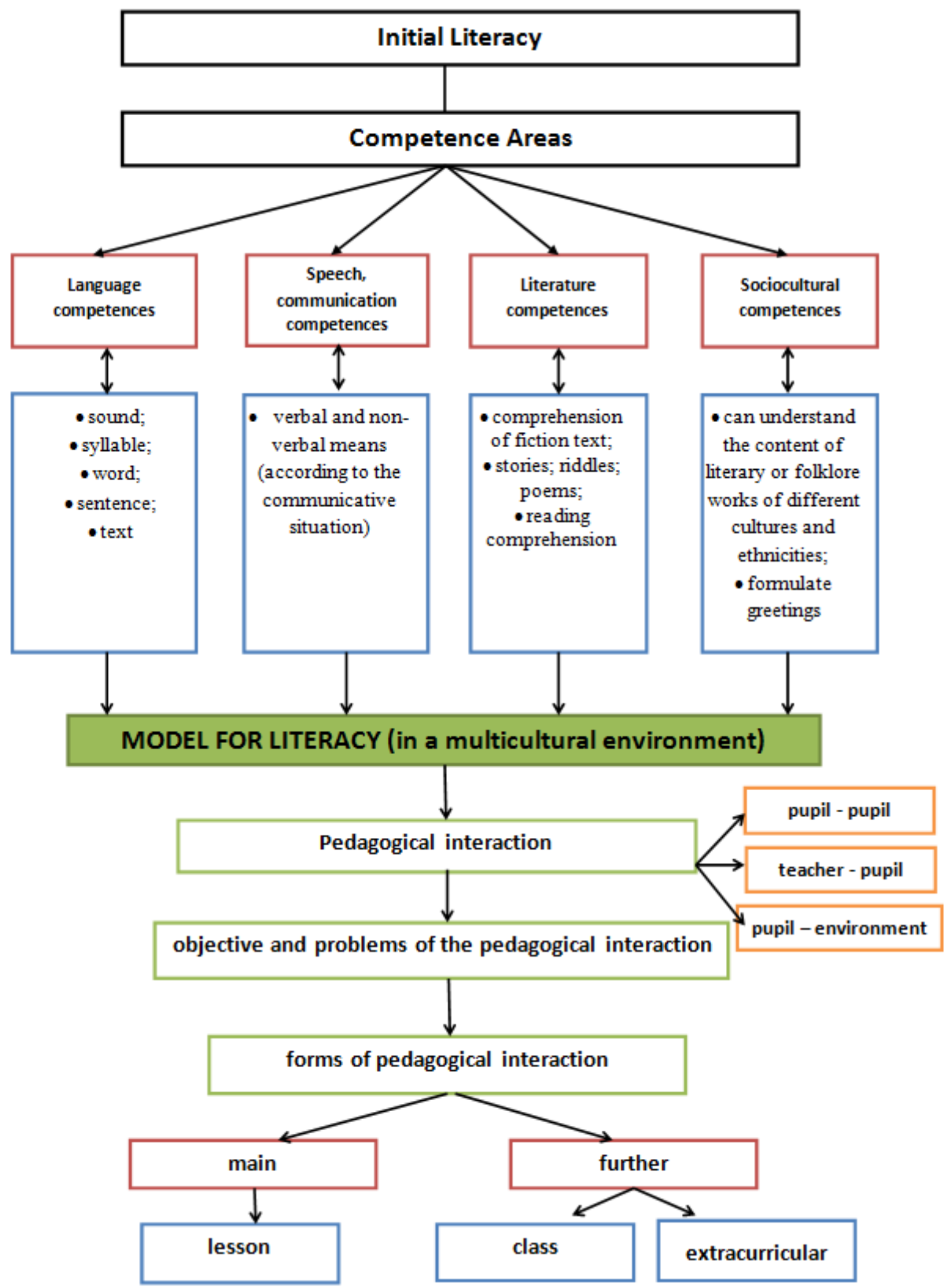




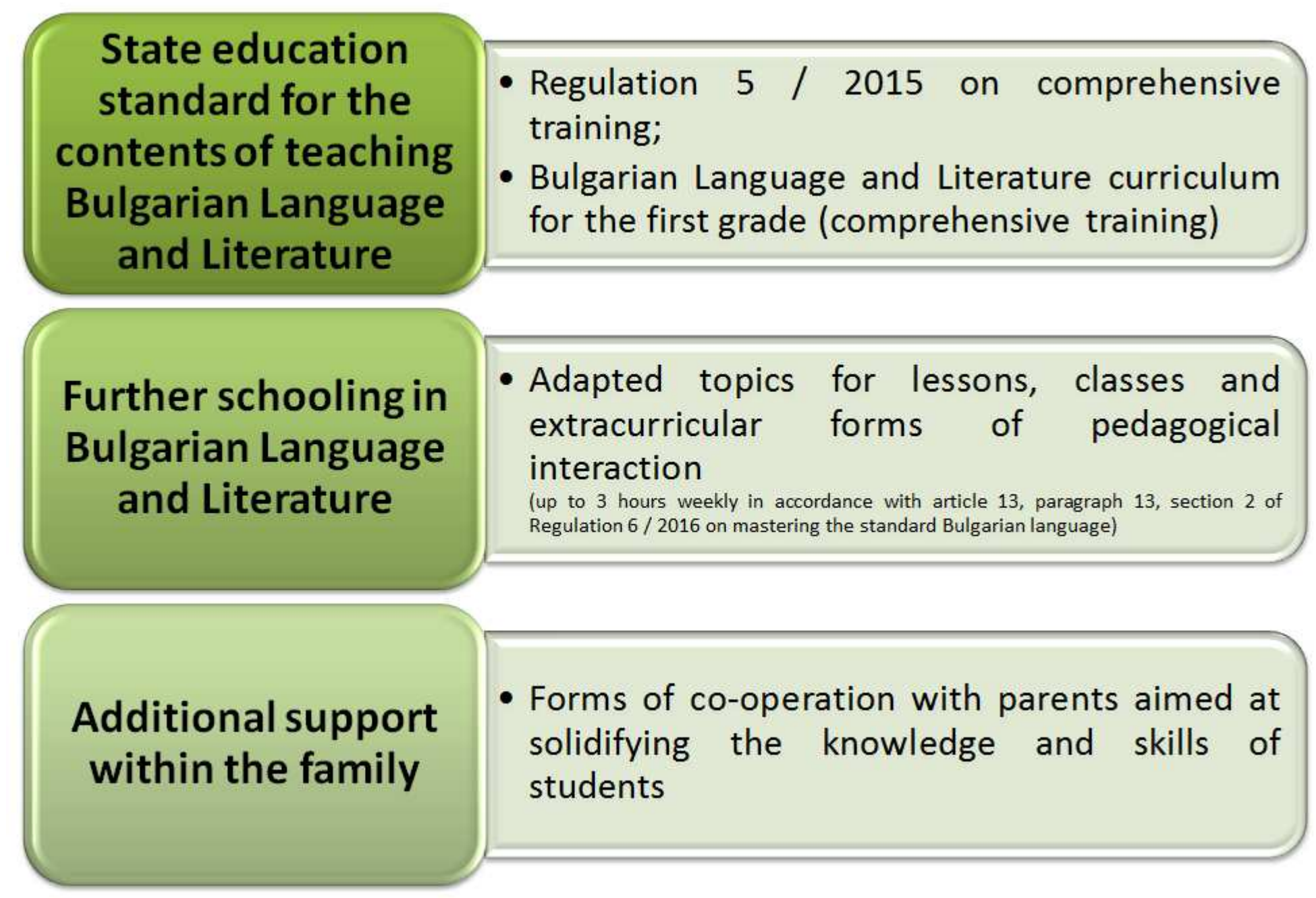


(JPMNT) Journal of Process Management - New Technologies, International

Vol. 5, No 3, 2017.

\section{References:}

[1] Zdravkova, 2004 / Здравкова, С. (2004): Ограмотяване на децата в условия на билингвизъм, София, Начално образование, бр. 3 , с. $3-8$

[2] Ivanova, 2014 / Иванова, Н. (2014): Обучението по български език и литература в началния етап на основната образователна степен, София, Рива

[3] Merdzhanova-Rasheva, 2016 / Мерджанова-Рашева, Я. (2016):
Концептуализация и метарефлексивни равнища на научно теоретикоемпирично изследване, София, Годишник на Софийския университет „Св. Климент Охридски“, Книга Педагогика, том 109, с. 5 - 33

[4] Regulation 6, 2016 / Наредба 6 от 2016 за усвояването на българския книжовен език, Министерство на образованието и науката, обн. ДВ. бр. 67 от 26 Август 2016г. 